Berkala Ilmu Perpustakaan dan Informasi, Vol. 15, No. 2, Desember 2019, Hal. 163-174 DOI: 10.22146/bip.39843

ISSN 1693-7740 (Print), ISSN 2477-0361 (Online)

Tersedia online di https://jurnal.ugm.ac.id/bip

\title{
Adaptasi pustakawan dalam menghadapi kemajuan teknologi
}

\author{
Mulyadi $^{1}$, Iskandar Zulkarnain ${ }^{2}$, Nurdin Laugu ${ }^{3}$ \\ ${ }^{1}$ Program Studi Ilmu Perpustakaan, Universitas Islam Negeri Raden Fatah Palembang \\ ${ }^{2}$ Program Pascasarjana, Universitas Islam Negeri Sunan Kalijaga Yogyakarta \\ ${ }^{3}$ Program Studi Ilmu Perpustakaan, Universitas Islam Negeri Sunan Kalijaga Yogyakarta \\ e-mail:mulyadi_uin@radenfatah.ac.id
}

Naskah diterima: 20 Oktober 2018, direvisi: 24 Oktober 2019, disetujui: 28 Oktober 2019

\begin{abstract}
ABSTRAK
Pendahuluan. Teknologi informasi memiliki dampak positif dan negatif pada pengguna dan membuat perubahan besar di perpustakaan. Di era digital, orang bebas untuk membuat dan mengakses informasi, membuatnya kelebihan beban. Artikel ini bertujuan untuk mengetahui bagaimana perpustakaan dan pustakawan lakukan ketika menghadapi teknologi yang berkembang pesat.

Metode penelitian. Makalah ini menggunakan studi literatur yang berkaitan dengan pengembangan teknologi perpustakaan. Makalah ini juga menerapkan observasi perpustakaan, mengacu pada sumber-sumber yang relevan dari berbagai media, seperti buku, jurnal, dan majalah.

Data analisis. Analisis data dengan mengumpulkan bacaan dan tulisan tentang adaptasi pustakawan, kemudian diklasifikasi, dianalisa, dibandingan, dan diinterpretasikan, sampai dapat kesimpulan.

Hasil dan Pembahasan. Hasil penelitian menunjukkan bahwa sebuah perpustakaan akan bertahan selama ia memiliki kemampuan untuk beradaptasi dengan perkembangan teknologi. Adaptasi membutuhkan kemampuan untuk mengakomodasi perubahan dramatis dan memiliki upaya untuk meningkatkan kemampuannya dalam menghadapi tantangan.

Kesimpulan dan Saran. Untuk bertahan, perpustakaan perlu meningkatkan kinerja dan layanannya berdasarkan kebutuhan pengguna.
\end{abstract}

Kata Kunci: Perpustakaan; Pustakawan; Digital; Adaptasi

\begin{abstract}
Introduction. Information technology has both positive and negative impacts on users and makes major changes in libraries. In digital era, people are free to create and access information, making it overload. This article aims to find out how libraries and librarians do when facing with rapidly advance technology.

Data collection method. This paper used literature study related to technology development of libraries. This paper also applied library observations, referring to relevant sources from various media, such as books, journals, andmagazines.

Analysis Data. Data analysis was conducted by classifying, analyzing, comparing, and interpreting data to obtain the conclusion.

Results and Discussions. The results showed that one library will survive as long as it has the ability to adapt with technology development. The adaptation needs an ability to accommodate dramatic changes and has an effort to improve its capabilities to face challenges.

Conclusions. To survive, a library needs to enhance its performance and services based on the users' need.
\end{abstract}

Keywords: Library; Librarian; Technology; Adaptation. 


\section{A. PENDAHULUAN}

Salah satu bentuk nyata dari kemajuan ilmu pengetahuan adalah teknologi yang diwujudkan dengan berbagai produk. Hasil dari teknologi tersebut digunakan untuk berbagai macam tujuan, tergantung kebutuhan dari lembaga dan individu masing-masing, yang salah satunya adalah untuk mempermudah pekerjaan. Sejak kemunculannya hingga saat ini, teknologi menjadi kebutuhan pokok yang tidak bisa dipisahkan dari manusia. Tekhnologi merupakan perpaduan antara rasionalisme dan logika manusia. Marshall McLuhan mengatakan human perception: then technological society would, fi nally, be transformed into a wonderful opportunity for the 'incarnation' of human experience (Birkl, 2014). Ia mengatakan tentang persepsi manusia bahwa, masyarakat teknologi pada akhirnya dapat berubah menjadi peluang luar biasa untuk membentuk pengalaman manusia. Pandangan ini kemudian berkembang dalam kehidupan manusia, bahwa teknologi merupakan faktor penentu utama dari perubahan sosial yang ada di masyarakat. Pandangan seperti inilah yang kemudian dikenal dengan determinasi teknologi, yang menganggap bahwa perubahan sosial disebabkan oleh penemuan teknologi, dengan asumsi bahwa penemuan teknologi menjadi kunci bagi kemajuan lembaga masyarakat.

Teknologi menjadi bagian yang tidak terpisahkan dari kehidupan global. Setiap institusi berupaya memaksimalkan teknologi guna membangun dan memberdayakan sumber daya manusia agar dapat bersaing di era global. Modernisasi telah membuat teknologi mengalami transformasi yang pesat dan masuk ke segala sendi kehidupan manusia. khususnya perpustakaan sebagai tempat penyebaran informasi. Teknologi juga semakin canggih yang membuat informasi semakin mudah diakses dan mempermudah aktivitas kerja manusia.

Perkembangan dunia digital sangat berpengaruh terhadap perkembangan perpustakaan. Hal ini karena perpustakaan merupakan sumber informasi yang banyak dibutuhkan oleh pemustaka baik dunia pendidikan maupun masyarakat umum, sehingga informasi yang disediakan harus selalu diperbarui. Untuk itu pengelolaan perpustakaan yang semula menggunakan peralatan manual dan dilakukan dengan cara-cara tradisional, sekarang beralih kepada pengolahan layanan berbasis teknologi digital yang banyak menggunakan peralatan canggih, seperti komputer, scanner, dan printer. Penerapan teknologi digital, merupakan perwujudan dari suatu perubahan pada layanan perpustakaan yang mendorong setiap perpustakaan untuk melakukan terobosan dan inovasi pelayanan yang modern dalam aktivitas kesehariannya.

Pada saat ini globalisasi membuat perpustakaan harus berevolusi, baik pada kegiatan layanan maupun pada kegiatan pengolahan koleksinya. Ditambah dengan kemajuan para pemustaka yang sudah mulai mengerti tentang teknologi, sehingga menuntut agar aktivitas di perpustakaan berjalan dengan cepat sesuai dengan teknologi yang berkembang, selanjutnya, para pustakawan juga dituntut agar lebih bersifat aktif dan selalu merespon kemajuan teknologi yang berkembang.

Tuntutan tersebut bertujuan untuk merespon net generation atau digital native. Yaitu, generasi yang sangat akrab dengan media digital. Hal tersebut tentu berbeda dengan generasi sebelumnya, yaitu digital immigrant yang berusaha mempelajari maupun membiasakan diri dengan berbagai perangkat teknologi yang ada. Digital immigrant ini masih belajar untuk beradaptasi dengan lingkungan baru namun tetap memelihara beberapa hal dari lingkungan masa lalu, walaupun ada beberapa digital immigrant yang mampu beradaptasi dengan sempurna dalam dunia teknologi informasi.

Keberadaan informasi menjadi demikian vital, dengan intensitas penggunaan yang demikian tinggi pada masyarakat abad modern yang menjadikan masyarakat tersebut dikategorikan sebagai masyarakat informasi. Meluasnya penggunaan teknologi oleh masyarakat merupakan karakteristik abad informasi. Masyarakat informasi merupakan masyarakat yang di dalamnya lebih banyak 
bekerja dengan memanfaatkan informasi dibandingkan peralatan manual, seperti yang digunakan dalam pertanian dan industri.

Demikian pula pada perpustakaan, beragam kegiatan yang bersifat rutin dan manual dapat digantikan oleh sistem komputer, sehingga peran pustakawan dapat dimaksimalkan dalam pengembangan layanan yang disesuaikan dengan karakteristik pemustaka di era global. Perpustakaan sebagai lembaga yang orientasinya melayani masyarakat penggunaanya harus tanggap dengan perubahan kalau tidak ingin ditinggalkan (Suwarno, 2016).

Saat ini para pustakawan tampaknya masih dominan dan cenderung bersifat teknis, yakni bekerja hanya menyimpan buku dan mengelola bahan pustaka, masih jarang melakukan aktivitas yang sifatnya membangun intelektual dengan melakukan penelitian dan kegiatan literasi yang dipadukan dengan teknologi informasi. Ini disebabkan karena belum maksimalnya peran perpustakaan dalam hal pengembangan sumber daya manusia dan ilmu pengetahuan. Para pustakawan harus mampu beradaptasi dengan dunia modern yang serba digital agar perpustakaan tetap berjalan dan berfungsi sebagaimana mestinya.

Perubahan tersebut akan terwujud jika memaksimalkan peran para pustakawan di dalam penyelenggaraan aktivitas perpustakaan. Dengan penyelenggaraan pengolahan dan layanan berbasis teknologi secara sistematis atau yang dikenal dengan perkembangan terkini dari otomasi perpustakaan. Aktivititas perpustakaan sudah tersistem, terintegrasi dari satu komputer ke komputer lainnya, sehingga satu pekerjaan dapat menyelesaikan pekerjaan lainnya karena sifat teknologi tersebut.

Penggunaan komputer dengan sistem tertentu yang terintegrasi antara satu dengan yang lainnya merupakan makna dari otomasi perpustakaan. Penggunaan ini mulai dari tahap pengembangan, pengolahan, dan penelusuran sampai dengan peminjaman dan pengembalian koleksi perpustakaan dikerjakan dengan sistem komputer yang terintegrasi. Sistem otomasi perpustakaan dapat diartikan penggunaan aplikasi atau software yang beroperasi berdasarkan pangkalan data untuk mengotomasikan kegiatan perpustakaan (Mulyadi, 2016). Otomasi merupakan kebutuhan tersendiri bagi sistem perpustakaan, untuk itu perlu pertimbangan dalam pemilihan sistem otomasi perpustakaan antara yaitu, nilai ekonomi, kehandalan, keluwesan, kebutuhan, kemudahan dalam pengoperasian, daya dukung purna jual dan fasilitas pelatihan yang memadai. Inilah langkah yang diperlukan dalam rangka memaksimalkan peran pustakawan untuk memadukan teknologi informasi dengan aktivitas pengolahan dan layanan di perpustakaan dengan mengembangkan aplikasi atau software yang sesuai dengan aturan dan penataan sistem di perpustakaan.

Layanan otomasi perpustakaan membuat beberapa pekerjaan dapat diselesaikan dalam satu pekerjaan, karena antara satu komputer dengan komputer yang lainnya sudah terintegrasi. Penggunaan komputer dengan menggunakan sistem otomasi mulai dari tahap pengembangan, pengolahan, penelusuran sampai dengan peminjaman dan pengembalian koleksi perpustakaan dikerjakan dengan sistem komputer yang terintegrasi. Perubahan tersebut sebuah upaya agar dapat berevolusi dan beradaptasi dengan lingkungan yang kompetitif (Shailesh, 2018). Jika para pustakawan tidak bisa beradaptasi dengan media baru tersebut, maka akan ketinggalan zaman, bahkan teori ini menganggap tersingkir bahkan punah. Sehingga, satu-satunya jalan yaitu harus berevolusi mengikuti perkembangan modernisasi.

Adaptasi membuat sistem pendidikan di berbagai bidang khususnya perpustakaan lebih interaktif dan lebih praktis dengan adanya teknologi digital seperti, menggunakan OHP, audio dan video pengajaran, dan yang lainnya, di tambah lagi dengan hadirnya internet. Sehingga berbagai aplikasi dapat diakses secara online dan suport bukan hanya dengan komputer tetapi media smartphone dan android. Permasalahan yang muncul dan perlu dicarikan solusi adalah bagaimana usaha dan yang dilakukan pustakawan dalam beradaptasi dengan dunia digital agar dapat terwujud budaya literasi digital? 
Penelitian ini perlu dilakukan sebagai upaya memberikan motivasi dan bekal kepada pustakawan dalam menghadapi teknologi dengan mengambil konsep digital Darwinism. Menurutnya, perubahan perekonomian yang terjadi di masa depan dengan adanya revolusi industri dengan menciptakan kembali kondisi ekonomi dan sosial yang mendalam dengan pengembangan teknologi digital yang berevolusi menuju globalisasi (Kreutzer, \& Karl, 2013). Kebaruan dari makalah ini bahwa konsep adaptasi dalam konteks sosial selama ini dimaknai samar maknanya luas berpotensi membingungkan, mengklaim yang sepintas benar padahal lemah secara logis, dan kecenderungan dinamis yang dipandang keliru. Sehingga untuk memecahkan butir persoalan tersebut dapat dilakukan penguatan tentang gagasan adaptasi digunakan dengan akurat tentang asal usulnya, gagasan yang kabur maka perlu penjelasan gagasan unggulnya (Giddens, 2010). Orisinalitas dari konsep ini dalam hal mengkaitkan teknologi dengan konsep evolusi Darwin, dengan asumsi bahwa hanya pustakawan yang mampu beradaptasi yang bisa bertahan, yakni jika tidak mampu beradaptasi, maka dapat dimaknai akan menemui kepunahan.

\section{B. TINJAUAN PUSTAKA}

Perkembangan teknologi memberikan tuntutan kepada pustakawan untuk mampu menyesuaikan diri atau beradaptasi (Rifnganti, 2016). Adaptasi merupakan sistem bagaimana suatu organisme melawan desakan lingkungan sekitarnya untuk bertahan hidup. Adaptasi diartikan sebagai bentuk penyesuaian diri terhadap lingkungan di mana seseorang bekerja dan belajar dengan munculnya pengembangan pengetahuan yang baru. Charles Darwin berpendapat bahwa : When technology and society evolve faster than your ability to adapt (Solis, 2016). Ia mengatakan bahwa teknologi dan masyarakat berkembang lebih cepat daripada kemampuannya untuk beradaptasi. Evolusi masyarakat dan teknologi, berdampak terhadap perilaku, harapan dan adat istiadat. Adaptasi merupakan upaya untuk mengubah tingkah laku terhadap lingkungan, budaya dan lainnya yang ada di sekitar kita, dengan memahami dan merespon perubahannya sehingga kita mampu bertahan.

Ketahanan dan keberhasilan tingkah laku bergantung pada pengetahuannya, kesadarannya tentang lingkungan yang ada disekitarnya. Ketidakmampuan seseorang untuk mengatasi teknologi komputer baru dengan cara yang sehat, dikenal dengan technostress atau sebuah penyakit adaptasi modern yang berjuang untuk menerima teknologi agar tidak gagap teknologi (Saidani, 2016). Adaptasi dapat dikatakan sebagai tindakan yang dilakukan seseorang untuk menjaga eksistensinya terhadap perubahan yang terjadi terhadap dirinya.

Dewasa ini masyarakat sudah masuk dalam suatu zaman baru di mana semuanya saling terhubung sehingga muncul istilah masa kini bahwa kita hidup di sebuah atmosfir masyarakat global (global village). Informasi datang begitu banyak dan cepat, sehingga teknologi informasi tidak bisa dibendung, yang dapat kita lakukan adalah merespon dan menganalisisnya sehingga kita dapat memanfaatkan dan memilih mana yang bermanfaat dan yang membahayakan diri, organisasi dan lingkungan, khususnya di tempat kerja.

Ada lima tipe yang membedakan individu dalam beradaptasi dalam situasi tertentu (Merton, 2010) yaitu :

1. Beradaptasi secara konformitas (conformity), yaitu, upaya yang dilakukan seseorang sesuai dengan norma yang berlaku. Misalnya,jika seseorang ingin mendapatkan gelar sarjana, maka tujuan itu akan dicapai dengan studi di perguruan tinggi. Adaptasi ini merupakan norma atau aturan masyarakat dalam memperoleh pekerjaan dengan menggunakan ijazah.

2. Innovation. Inovasi yaitu suatu upaya yang dilakukan seseorang untuk mencapai tujuan, tetapi mengabaikan norma yang berlaku di masyarakat. Sebagai siswa, misalnya, jika ingin memperoleh nilai biologi bagus, maka harus melakukan berbagai cara dan upaya, baik belajar maupun mencontek pada saat ujian. Jika belajar maka nilainya sesuai dengan norma 
dan merupakan tujuan yang ditetapkan oleh masyarakat atau lembaga, tetapi mencontek merupakan cara yang tidak dibenarkan oleh masyarakat.

3. Ritualism. Ritualisme sering diartikan sebagai upaya penyesuaian diri seseorang kepada suatu kondisi dengan tanpa mempertimbangkan tujuan, tetapi caranya sesuai dengan norma yang berlaku dan ada di masyarakat. Contohnya, seorang karyawan dari kalangan menengah ke bawah tidak ingin naik pangkat atau jabatan. Ia tidak berharap dan tidak ada keinginan sebab takut gagal. Tujuan budaya yang telah ada di masyarakat (mencapai kesuksesan) maka ia tidak mengejar jabatan tersebut, tetapi cara mencapai tujuan budaya tetap ia lakukan, yaitu dengan bekerja.

4. Retreatisme (retreatism). Retreatisme sebagai upaya yang dilakukan seseorang untuk menarik diri dari sistem yang ada. Seseorang bertindak tidak lagi berdasarkan pada norma dan tujuan yang berlaku dalam masyarakat. Pola adaptasi ini dapat dilihat pada orang yang mengalami gangguan jiwa, gelandangan, pemabuk dan para pecandu narkoba. Orang-orang itu ada di dalam masyarakat, tetapi dianggap tidak menjadi bagian dari masyarakat, karena memiliki gangguan pada kejiwaannya.

5. Pemberontakan (rebellion). Pada bentuk adaptasi ini seseorang tidak lagi mengakui struktur sosial yang ada dan berupaya menciptakan struktur sosial yang baru. Tujuan yang ada dianggap sebagai penghalang bagi tujuan yang diharapkan. Demikian pula dengan cara yang ada untuk mencapai tujuan tersebut tidak diakui masyarakat. Sebagai contoh, pada tahun 1998 terjadi demonstrasi mahasiswa dari seluruh perguruan tinggi di Indonesia yang berhasil menurunkan rezim ordebaru, kemudian menggantinya dengan rezim reformasi. Orde baru merupakan rezim yang ditolak oleh mahasiswa dan masyarakat, sedangkan reformasi merupakan struktur sosial yang didambakan oleh masyarakat dan dianggap mampu menghadapi problem negara dan masyarakat.

Dari semua tipe yang disebutkan, tipe adaptasi konformitas merupakan bentuk perilaku yang tidak menyimpang. Sementara tipe yang lain merupakan bentuk perilaku yang menyimpang. Konformitas merupakan suatu tindakan yang tidak tertulis dari kelompok teman sebaya terhadap anggotanya tetapi memiliki pengaruh kuat dan dapat menyebabkan munculnya perilaku-perilaku tertentu pada anggota kelompok (Uswah, 2016). Pada dasarnya pemikiran kita semua lebih cenderung bersifat konformis. Dalam interaksi dan sosialisasi sehari-hari, sesorang cenderung menyesuaikan diri dengan orang lain atau dengan kelompoknya sendiri. Proses interakasi dan sosialisasi itulah yang kemudian menghasilkan konformitas

Konformitas merupakan bentuk interaksi yang di dalamnya seseorang berperilaku terhadap orang lain sesuai dengan harapan kelompok atau masyarakat di mana dia tinggal. Konformitas berarti proses penyesuaian diri dengan masyarakat dengan cara mentaati norma-norma atau nilai-nilai masyarakat. Sementara itu, perilaku yang menyimpang atau tidak sesuai dengan norma dan etika yang berlaku merupakan perbuatan yang menyimpang dan tentunya harus dihindari.

\section{METODE PENELITIAN}

Metode penelitian yang digunakan adalah studi literatur. Riset literatur (library research) adalah serangkaian kegiatan yang berkenaan dengan metode pengumpulan data pustaka, membaca dan mencatat serta mengolah bahan penelitian (Zed, 2014). Penelitian ini dilakukan dengan meneliti data kepustakaan secara mendalam terhadap sejumlah buku, jurnal, laporan lapangan dan semacamnya yang secara khusus memiliki hubungan dengan kajian adaptasi pustakawan terhadap perkembangan teknologi. Data juga ada yang diperoleh dari penelusuran situs web perpustakan melalui internet. Setelah data didapat, tahap selanjutnya data dianalisis dengan tujuan untuk mencari informasi faktual secara detail tentang sejauhmana kemampuan para pustakawan 
dalam beradaptasi dengan kemajuan teknologi yang masuk ke dalam perpustakaan. Sehingga, mendapatkan gambaran yang jelas tentang pengembangan perpustakaan dengan masuknya teknologi modern.

Teknik pengumpulan data dilakukan dengan cara: Pertama, pencarian informasi dari para ahli di bidang kajian perpustakaan dan teknologi, dalam hal ini melakukan pengkajian serta melacak dan mengumpulkan karya-karya mereka melalui buku dan situs jurnal nasional maupun internasional yang kredibel. Kedua, validasi beberapa sumber literatur dilakukan dengan proses mengklasifikasi menjadi dua bagian yaitu tentang perpustakaan dan teknologi. Ketiga, melakukan pengkajian mendalam terhadap beberapa literatur, memilih bagian-bagian penting dan membandingkan antara sumber literatur yang satu dengan yang lainnya, mengkritisi, dan merujuknya. Sedangkan teknik analisis data dalam penelitian ini dimulai dengan menelaah seluruh data yang tersedia dari berbagai sumber. Setelah data terkumpul, lalu diklasifikasikan sesuai dengan masalah yang dibahas yang selanjutnya dilakukan analisis dan dibandingkan dengan data yang lainnya, kemudian diinterpretasikan dan akhirnya diberi kesimpulan.

\section{HASIL DAN PEMBAHASAN Usaha Pustakawan Menghadapi Kemajuan Teknologi}

Perkembangan perpustakaan yang dibarengi dengan kemajuan teknologi mengalami perubahan pengertian sesuai dengan fungsi, manfaat dan kegunaannya. Sejak awal munculnya perpustakaan sampai era digital sekarang, perpustakaan dapat dibedakan ke dalam beberapa kelompok, yaitu, perpustakaan manual (gedung, lokasi, koleksi tercetak, ruang baca dan meja referensi), perpustakaan elektronik (gedung, lokasi fisik, koleksi tercetak dan elektronik, ruang baca dan meja referensi), perpustakaan hibrida (gedung, lokasi fisik, internet, koleksi tercetak, elektronik, digital, ruang baca, meja referensi, referensi maya, ruangan maya/virtual), perpustakaan digital (dengan atau tanpa lokasi fisik, koleksi digital, referensi maya), dan perpustakaan maya (tanpa lokasi fisik, koleksi seluruhnya digital, ruang dan referensi maya) (Mulyadi, 2016).

Pada era globalisasi sekarang ini setiap perpustakaan sudah berusaha pada tahap perpustakaan hibrida. Artinya, sudah menggunakan koleksi tercetak dan digital yang dilayankan di internet, sedangkan untuk perpustakaan maya yang semua koleksinya digital masih terbatas di Indonesia karena peralatan dan teknologi masih belum memadai. Internet dapat dilihat sebagai perpanjangan atau kelanjutan dari transisi pencarian informasi terpasang yang berfungsi sebagai alat untuk berkomunikasi antarilmuan secara langsung maupun tidak langsung sebagai perpanjangan tangan fungsi para pustakawan yang bekerja di perguruan tinggi, maupun pusat-pusat riset.

Sistem informasi bermakna hubungan yang saling terkait antara manusia dan mesin bekerja secara terpadu untuk menyajikan informasi guna mendukung fungsi operasi, manajemen dan pengambilan keputusan dalam sebuah organisasi. Dengan kata lain, sistem informasi merupakan kesatuan elemen-elemen yang mendukung pembuatan keputusan dan dapat melakukan kontrol terhadap jalannya suatu organisasi. Sistem informasi ini dapat saling berinteraksi secara sistematik dan teratur untuk menciptakan dan membentuk aliran informasi yang diperlukan. Sistem informasi adalah sekumpulan sub sistem di suatu perpustakaan yang saling berinteraksi satu sama lain untuk mencapai tujuan bersama berupa pengelolaan dan penyediaan informasi perpustakaan sehingga apabila informasi diperlukan dapat disediakan dengan cepat, mudah dan lengkap (Mutaqin, Zaini \& Eka, 2013).

Teknologi berkembang secara dinamis, dan selalu mengalami inovasi serta perubahan. Teknologi dapat dianalogikan sebagai arah gerak sains yang dapat menjelaskan berbagai pengetahuan tentang cara pandang dan pengalaman yang membentuk cara bertindak, menggunakan alat dan cara kita berhubungan dengan dunia luar. Ledakan informasi membuat para pustakawan tidak hanya bekerja antar sesama pustakawan tetapi juga dengan profesi lainnya, untuk memaksimalkan pelayanan pemakai. Pemanfaatan teknologi untuk kegiatan 
perpustakaan sejalan dengan tuntutan masyarakat kepada para pustakawan untuk mengadopsi berbagai perkembangan lingkungan yang mengalami perubahan sangat cepat. Kualitas pelayanan menjadi ukuran manfaat atau tidaknya suatu perpustakaan yang meliputi, pelayanan administrasi, pengadaan koleksi dan pendayagunaan koleksi (Wahyuni, 2015). Untuk mengimbangi kebutuhan pemustaka yang tidak hanya hidup di dunia nyata, pustakawan harus keluar dari zona aman, untuk bertemu dengan mereka ke ruang yang dikenal dengan virtual.

Istilah virtual sering diartikan untuk menandakan suatu ketiadaan, sesuatu yang tidak nyata. Obrolan sehari-hari di media menyamakan kenyataan dengan hal konkret, materi perwujudan, kehadiran nyata dan kehandalan. Hal tersebut menunjukkan bahwa virtual adalah sesuatu yang bersifat tiruan. Virtual jika diartikan secara filosofis adalah suatu refleksi dari kegiatan dan objek alamiah yang ada namun tidak konkret, dengan kata lain virtual adalah nyata namun tidak konkrit. Dalam konteks teknologi dan bentuk sosialnya dalam dunia kerja, dan dalam telekomunikasi maju, virtual menyamakan kepada sesuatu hal yang disimulasikan. Sesuatu yang esensinya tidak lengkap tetapi dijadikan alternatif dari suatu kenyataan. Ruang virtual melibatkan konstruksi dalam jaringan tanpa kabel.

Ruang virtual sudah menjadi suatu fenomena yang dapat diterima oleh masyarakat. Masyarakat modern terlihat pertumbuhannya dalam media sosial sebagai komunitas dari berbagai sekat dan jenis kebutuhan. Jaringan media sosial merupakan contoh dari masyarakat virtual dalam melakukan komunikasi seseorang dengan yang lainnya, baik dengan kelompok ataupun pribadi yang dapat dilakukan hanya dengan layar komputer. Komunikasi massa sudah menciptakan masyarakat baru dalam ruang virtual yang dibentuk melalui komunikasi media massa yang telah terhubung ke seluruh belahan dunia tanpa pandang ras, agama, status sosial, dan tanpa terbatas ruang dan waktu. Ruang virtual ini menawarkan beragam kelebihan dan kemudahan dibandingkan dengan konvensional. Selain itu juga dapat membangun komunikasi dari dua arah yang dapat menjangkau hal yang jauh dalam jaringan yang luas. Apapun bentuknya yang harus dilakukan pustakawan adalah meresponnya dengan kalimat adaptasi. Karena, menghadapi era globalisasi dua tantangan besar yang harus diatasi oleh para pustakawan, yaitu, pertama, pustakawan harus mampu menyelaraskan bahan pustaka dengan format yang sesuai dengan perkembangan teknologi informasi. Kedua, mereka dituntut untuk memberikan layanan serba cepat serta lebih bersikap aktif (Hidayat, 2016). Untuk itu dibutuhkan adaptasi agar perpustakaan tampil seperti yang diharapkan oleh pemustakanya.

Lahirnya generasi net melahirkan inspirasi untuk perpustakaan dalam menjawab tantangan kebutuhan yang harus dipenuhi bagi pemustaka. Generasi net juga membawa angin segar bagi perpustakaan untuk merevitalisasi peran dan fungsinya sebagai lembaga pengelola informasi yang semakin luas, canggih, dan beragam yang serba digital. Pemberdayaan perpustakaan digital dan teknologi informasi di era global ini harus dilakukan mulai saat ini, agar pada saatnya nanti tidak ragu lagi menghadapi baik luapan informasi maupun tuntutan pengguna. Teknologi informasi memiliki dua komponen yaitu komputer dan telekomunikasi.

Internet merupakan pengembangan jaringan elektronika tanpa menggunakan kabel dengan menggunakan bantuan alat telekomunikasi. Internet menyimpan berbagai informasi yang dapat dianalogikan sebagai rimba raya, tempat semua jenis flora dan fauna hidup, tumbuh dan berkembang berupa data dan informasi. Di masa perkembangan teknologi informasi yang pesat ini pustakawan harus berupaya membangun kompetensi dirinya, karena perubahan informasi global ini selalu bersentuhan dengan teknologi sehingga yang dilakukan harus mengembangkan kompetensi dan beradaptasi agar mampu mengikuti perkembangan tersebut.

Adaptasi memerlukan keterbukaan dalam menerima setiap perubahan dan selalu berusaha meningkatkan kapasitas diri dan lembaga. Era informasi elektronik memberikan peluang baru bagi organisasi untuk menghasilkan serta 
menggunakan produk informasi. Pustakawan era baru, mempunyai keakraban dengan pasar informasi, dapat berkontribusi dalam pengembangan, pemasaran dan penggunaan produk informasi. Adaptasi di era digital mengubah cara pengolahan dan layanan dengan adanya aplikai software yang basisnya website, sehingga mengubah wajah perpustakaan dari konvensional menjadi terotomasi berbasis online dengan internet sebagai penunjangnya (Priyanto, 2016).

Dunia digital dikenal juga dengan abad 21, pada masa ini semua informasi berubah dan beradaptasi ke dunia digital. Hal tersebut merupakan beban dan tugas pustakawan untuk dapat mengembangkan perpustakaan yang memiliki daya saing terhadap organisasi/ lembaga pengelola informasi lainnya di masa mendatang. Peran pustakawan menjadi lebih berat karena dituntut bekerja lebih efisien dan efektif dalam memberikan pelayanan kepada pemustaka. Menghadapi hal tersebut pustakawan harus mempersiapkan diri dan beradaptasi ketika berurusan dengan teknologi baru. Peran pustakawan menjadi ganda di samping beradaptasi juga memberikan perubahan terhadap lingkungan dengan menjadi sumber informasi bagi pemustaka yang memanfaatkan teknologi di perpustakaan (Jamridafrizal, 2017). Beberapa usaha yang harus dilakukan oleh para pustakawan dalam menghadapi dunia digital abad 21 adalah dengan beradaptasi (Trilling, 2016). Sebagaimana dapat dilihat berikut ini :

1. Keterampilan hidup dan berkarir melalui beberapa usaha antara lain :

a. Memiliki kemampuan untuk beradaptasi dan fleksibel dengan berbagai perkembangan dunia kerja/lingkungan dalam rangka meningkatkan kualitas layanan perpustakaan. Pustakawan harus mampu melaksanakan tugas dan menyesuaikan diri pada setiap layanan perpustakaan di mana dia ditugaskan, serta mampu mendayagunakan sarana dan prasarana yang telah diimplementasikan sebagai bentuk inovasi layanan perpustakaan. b. Memiliki inistiatif untuk melaksanakan pekerjaan dengan lebih efektif dan efisien, serta mampu mengembangkan karirnya sebagai pustakawan secara mandiri. Pustakawan harus mampu memberikan ide dan konsep pengembangan perpustakaan baik secara lisan kepada pimpinan maupun gagasan konseptual yang dituangkan dalam bentuk tertulis (misalnya artikel).

c. Interaksi sosial dan antar-budaya, pustakawan mampu bekerja/ berinteraksi secara aktif dan efektif dengan berbagai elemen dalam suatu organisasi dengan beragam karaktersitik. Pustakawan memberikan kualitas layanan yang sama pada semua pemustaka dan berinteraksi dengan berbagai macam elemen pada suatu organisasi tanpa memandang perbedaan status, etnis maupun profesi.

d. Produktivitas dan akuntabilitas di kalangan pustakawan dalam menentukan dan melaksanakan pekerjaan sesuai dengan target yang telah ditentukan secara mandiri dalam rangka pengembangan karir profesi pustakawan.

e. Pustakawan memiliki kapasitas kepemimpinan dan tanggung jawab terhadap pekerjaan yang telah dilaksanakan dalam rangka kemajuan perpustakaan.

2. Keterampilan belajar dan berinovasi, dengan melakukan beberapa hal berikut :

a. Berpikir kritis dan mengatasi masalah, pustakawan mampu mengidentifikasi dan menganalisis berbagai fakta/persoalan yang ada untuk mendapatkan solusi untuk memecahkan berbagai macam permasalahan kerja.

b. Komunikasi dan kolaborasi, keterampilan komunikasi merupakan salah satu bekal yang diperlukan pustakawan untuk mewujudkan 
layanan prima perpustakaan. Pustakawan mampu berkolaborasi dengan berbagai elemen dalam suatu organisasi dalam meningkatkan kualitas layanan perpustakaan.

c. Kreativitas dan inovasi, unsur kreativitas, sangat diperlukan agar pustakawan dapat berperan sebagai motor penggerak inovasi layanan perpustakaan dari masa ke masa demi mewujudkan visi perpustakaan sebagai jantung pendidikan. Inovasi perpustakaan harus dikembangkan sesuai dengan kebutuhan informasi generasi $\mathrm{Z}$ generasi milenial yang menitik beratkan pada kemudahan akses informasi (misalnya pengembangan repository).

3. Keterampilan memanfaatkan informasi, media dan teknologi, diantaranya adalah sebagai berikut :

a. Literasi informasi, pustakawan mampu mengakses/memanfaatkan sumbersumber informasi dengan baik, mengidentifikasi dan menganalisis informasi secara kritis, serta menggunakan informasi secara efektif untuk mengatasi berbagai permasalahan.

b. Literasi media, pustakawan mampu memilih dan mengembangkan berbagai macam media yang tersedia untuk meningkatkan kualitas layanan perpustakaan dan meningkatkan komunikasi/interaksi dengan pemustaka.

c. Literasi teknologi informasi dan komunikasi, pustakawan mampu menggunakan atau mengoperasikan berbagai peralatan teknologi dan sejenisnya yang dipergunakan di perpustakaan dan dapat digunakan untuk meningkatkan kualitas layanan perpustakaan.

Menghadapi berbagai tantangan dalam dunia digital, para pustakawan harus mampu menyesuaikan diri dan memiliki kompetensi. Teknologi baru yang berkembang dan masuk ke perpustakaan dapat diimplementasikan dalam aktivitas di perpustakaan maupun untuk para pemustaka yang berkunjung di perpustakaan. Opini dari masyarakat bahwa ruang realitas sekarang ini dapat tersaingi oleh ruang virtual dengan menggeser beberapa pola dan aspek dalam kehidupan sosial masyarakat. Ruang virtual terbentuknya dari jaringan komputer yang terhubung dari kabel-kabel dan informasinya secara global. Virtual merupakan sebuah ruang yang sifatnya imajiner, setiap orang yang tergabung dalam ruang virtual dapat melakukan hal-hal yang biasanya dilakukan dalam ruang realitas dengan cara mengandalkan kecanggihan teknologi (Piliang, 2018). Tetapi apabila para pustakawan sudah dibekali dengan kompetensi dan mampu beradaptasi maka teknologi yang berkembang justru merupakan sarana untuk mencapai kemajuan di perpustakaan.

Tantangan lain yang dihadapi perpustakaan dengan adanya dukungan pada kemajuan teknologi yang dapat diadaptasi ini, adalah para pustakawan harus mampu sebagai sentral pendidikan tempat bertanya dan mendapatkan informasi bagi pemustaka. Para pustakawan tidak sebatas melakukan aktivitas sirkulasi dan pengolahan saja, tetapi juga bisa memberikan aktivitas kegiatan sosial lainnya yang bermanfaat bagi pemustaka maupun masyarakat luas. Oleh karena itu perpustakaan dan pustakawan harus terus mengenali lembaga dan diri serta merespon setiap kemajuan teknologi baru yang datang ke perpustakaan.

\section{Peran Pustakawan dalam Proses Adaptasi Digital}

Kebutuhan teknologi informasi sangat berhubungan dengan peran pustakawan dalam perpustakaan. Pustakawan adalah Pegawai Negeri Sipil (PNS) yang diberi tugas, tanggung jawab, wewenang dan hak untuk melaksanakan kegiatan kepustawanan (PNRI, 2015). Dewasa ini pustakawan menghadapi berbagai tantangan yang cukup berat sehubungan dengan adanya suatu evolusi dari perpustakaan klasik menuju perpustakaan modern. Tantangan profesi pustakawan tersebut bertambah berat, ketika dihadapkan dengan pemenuhan keinginan pemustaka yang menghendaki manajemen dan 
layanan perpustakaan sesuai dengan teknologi modern sebagaimana negara-negara maju yang telah menerapkan teknologi modern.

Peran pustakawan dalam pemanfaatan teknologi informasi digital sebagai penunjang dalam menjawab tuntutan pengguna sangat diperlukan. Jika perpustakaan tidak memaksimalkan peran pustakawan dan mengimbangi perkembangan teknologi, maka perpustakaan akan kehilangan peminatnya (Rahmawati, 2017). Interaksi sosial antara pemustaka dengan pustakawan merupakan hal yang sangat penting agar keberadaan perpustakaan menjadi salah satu daya tarik dalam kehidupan pemustaka. Salah satu tugas pustakawan yaitu memberikan layanan maksimal kepada para pemustakanya, untuk itu membutuhkan keterampilan sosial yang baik pada saat berhadapan dengan para pemustaka. Jika pustakawan memiliki keahlian dalam bidang teknologi informasi, maka pemanfaatkan berbagai jenis produk dan sistem teknologi informasi yang senantiasa berkembang di perpustaakaan akan dapat tercapai.

Perpustakaan sebagai kekuatan dalam pelestarian dan penyebaran ilmu pengetahuan yang berkembang seiring dengan kegiatan menulis, mencetak, mendidik serta pemenuhan kebutuhan masyarakat tentang pentingnya informasi. Permasalahan yang ada di perpustakaan tersebut hanya dapat diselesaikan dengan membangun sebuah sistem teknologi informasi yang sesuai dengan kebutuhan pengguna. Sistem teknologi yang dibangun tersebut tidak hanya untuk mengelola perpustakaan saja, tetapi juga kreasi baru, penyebaran dan akses sumber informasi dalam bentuk digital melalui jarigan komputer.

Pada perpustakaan tradisional peran pustakawan meliputi seleksi, menelusur, mengkoleksi, mengorganisasi, menjaga dan memelihara sumber informasi. Salah satu hal yang terpenting dalam perpustakaan manual atau tradisional adalah klasifikasi dan katalogisasi untuk menentukan dan memberikan kode pada buku sehingga bisa di letakan di rak yang telah ditentukan dan untuk mempermudahkan temu kembali. Katalog perpustakaan dapat diartikan sebagai daftar pustaka yang ada di perpustakaan. Sedangkan katalogisasi adalah suatu proses pembuatan katalog yang mencakup kegiatan menentukan diskripsi fisik dokumen dan menggunakan peraturan pengkatalogan yang bersifat internasional dan memberinya nomor panggil. Dengan masuknya teknologi modern segala rutinitas manual dalam perpustakaan tradisional dapat dikerjakan dengan menggunakan bantuan berbagai sistem aplikasi perpustakaan.

Pemenuhan kebutuhan pemustaka dalam rangka mencerdaskan kehidupan bangsa, para pustakawan memaksimalkan segala kemampuan intelektualnya, tetapi juga tidak meninggalkan semua kegiatan rutinitas kepustakawanannya. Inilah keistimewaan seorang pustakawan, selain memiliki kemampuan di bidang teknis, tetapi juga menguasai teori dan wawasan keilmuan yang bisa mengembangkan diri dan organisasinya. Terlebih lagi di zaman era modernisasi sekarang ini berbagai informasi mudah didapat dengan cepat, para pustakawan harus menjadi penerima informasi pertama dan kemudian menyebarkanya untuk kepentingan para pemustaka.

Pustakawan merupakan profesi yang memiliki beberapa tugas pokok dan fungsi yang sepesifik. Tiga kunci utama yang digunakan untuk menjalankan strategi kepuasan (satisfaction) bagi pengguna perpustakaan yaitu, memahami kebutuhan pengguna, pengembangan database yang akurat, dan pemanfaatan informasi yang didapat dari riset (Rahmah, Makmur, \& Testiani, 2015). Perpustakaan yang mutakhir sekalipun dengan berbagai perangkat teknologi modern tidak akan menarik hati para pemustakanya jika tidak ada layanan dari para pustakawan yang menyenangkan.

Pustakawan harus bekerja dengan hati yang ikhlas dan dapat menyikapi segala tantangan dan persoalan dengan cara yang bijaksana. Setiap permasalahan baik yang ada di pengolahan maupun layanan harus diselesaikan dengan cara musyawarah sesama pustakawan sehingga para pemustaka merasakan bahwa perpustakaan benar-benar merupakan tempat 
untuk menyelasaikan masalah dan solusi setiap persoalan yang berkaitan dengan akademik dan informasi yang bermanfaat untuk semua kalangan.

Para pustakawan yang bertugas harus mempersiapkan segala sesuatunya agar tercipta layanan yang maksimal. Pustakawan harus memiliki kemampuan yang dapat digunakan dalam aktivitasnya. Kemampuan tersebut harus memiliki kepandaian dalam bidang teknologi informasi (skills), wawasan luas (knowledge), dan dapat memberikan layanan (ability), serta kedewasaan psikologis, dalam upaya mengangkat profesionalitas pustakawan yang berkaitan dengan era informasi (Setyorini, 2017). Kualitas layanan yang baik dan diminati menjadi ukuran manfaat atau tidaknya suatu perpustakaan bagi penggunanya.

\section{E. KESIMPULAN}

Perpustakan adalah salah satu lembaga yang menerapkan teknologi, karena perpustakaan merupakan institusi pengelola informasi yang membutuhkan teknologi dalam penyebarannya. Pemanfaatan teknologi di perpustakaan diantaranya dengan adanya otomasi perpustakaan, yang kemudian berkembang menjadi perpustakaan digital atau cyber library, yang menghasilkan layanan yang cepat dan tepat. Usaha yang harus dilakukan para pustakawan dalam menghadapi perkembangan teknologi mutakhir adalah dengan cara mengembangkan kompetensi diri dan beradaptasi dengan dunia digital. Teknologi yang canggih ditambah dengan alat komunikasi akan melahirkan model pengolahan dan layanan baru di perpustakaan, maka dalam aktivitas kesehariannya para pustakawan akan mengalami kemudahan dan lebih efektif dalam bekerja. Untuk mencapai seluruh aktivitas dengan adanya peralihan dari perpustakaan manual ke perpustakaan digital maka diperlukan peran dari para pustakawan dalam menjalankan tugas dan tanggung jawabnya di perpustakaan. Tuntutan perubahan yang semakin besar terhadap perpustakaan sebagai pencerdas kehidupan bangsa melalui pendidikan dan pengajaran dengan menyediakan berbagai bahan pustaka, semakin menjadi tantangan bagi perpustakaan untuk berinovasi dalam segala hal agar dapat memberikan layanan yang terbaik bagi pengguna. Pustakawasn harus membekali dirinya dengan kompetensi, baik di bidang teknologi maupun sosial. Jika pustakawan mampu beradaptasi dan memaksimalkan perannya, maka apa yang diharapkan oleh para pemustaka dapat terpenuhi dengan cepat dan tepat. Agar sistem perpustakaan tetap berjalan, maka penentu kebijakan dalam perpustakaan harus membuat program dan rencana yang sistematis terkait dengan perkembangan teknologi sehingga sistem dan fungsinya tetap berjalan walaupun terjadi pergantian pemangku kebijakan.

\section{DAFTAR PUSTAKA}

Birkl, C. (2014). McLuhan's global village today. USA: Pickering \& Chatto.

Hidayat, A. (2016). Rekontruksi peran pustakawan di era globalisasi. LIBRARIA, 4(2), 467-480.

Giddens, A. (2010). Teori strukturasi: Dasadasar pembentukan struktural masyarakat. Yogyakarta: Pustaka Pelajar.

Jamridafrizal. (2017). Siapkah pustakawan menghadapi era digital. Al-Maktabah, 16(1), 41-50.

Kreutzer, R.T. \& Karl, H.L. (2013). Digital darwinism: Branding and business modelsin jeopardy. New York: Springer Heidelberg.

Merton, R.K. $\left.\left(\Upsilon^{\prime} \cdot\right)^{\bullet}\right)$. Science, technology and society in seventeenth century england, Osiris, 4(1), 360-632.

Mulyadi. (2016). Pengelolaan otomasi perpustakaan berbasis senayan library management system (SLiMS). Jakarta: Rajawali Pers.

(2016). Pengelolaan perpustakaan digital. Palembang: NoerFikry Press.

Mutaqin, M., Zaini \& Eka K. (2013). Dasardasar teknologi informasi. Jakarta: Universitas Terbuka.

Piliang, Y.A. (2012). Masyarakat informasi dan digital: Teknologi informasi dan pergeseran sosial, Jurnal Sosioteknologi, 27(11), 143156. 
PNRI. (2015). Peraturan kepala perpustakaan nasional RI nomor 11 Tahun 2015 tentang juknis jabatan fungsional pustakawan dan angka kreditnya. Jakarta: Perpusnas RI.

Priyanto, I.F. (2016). Teknologi informasi dan peran perpustakaan. Makalah Seminar Nasional Perpustakaan pada Universitas Islam Indonesia, Yogyakarta, Diterima dari: https://docplayer.info/48810881Teknologi-informasi-dan-peranperpustakaan.html. Tanggal akses 21 Agustus 2019.

Rahmah, E., Makmur, \& Testiani. (2015). Kebijakan sumber informasi perpustakaan. Yogyakarta: Graha Ilmu.

Rahmawati, N.A. (2017). Penggunaan teknologi informasi dalam pelayanan sumber informasi di perpustakaan. LIBRIA, $9(2), 125-132$.

Rifnganti, E. (2016). Tantangan pustakawan perguruan tinggi dalam memberikan layanan prima dengan berbasis teknologi informasi. Jurnal Dinamika Pendidikan, 16(2), 263-278.

Saidani, N. (2016). Towards a better somprehension of adaptation to onformation and communication technologies: A multi-level approach, (Disertation at the Georgia State University), pp.39-41 Retrieved from https://pdfs.semanticscholar.org/66ad/278 ad0ee8320b2b16490dcb9c8bdc5efd443.p df. Tanggal akses 21 Agustus 2019.
Setyorini, E. (2017). Peran pustakawan di era informasi. Artikel Repository Universitas Airlangga Surabaya, 28-32, http:// repository.unair.ac.id/id/eprint/58961.

Shailesh G., \& Priya V. (2018). Digital darwinism and branding: In context to educational institutions-a conceptual view. International Journal of Business and Management Invention (IJBMI), 7(5), 3741.

Solis, B. (2016). Disruptif \& technologi trends 2016-2018. Las Vegas: Altimeter.

Suwarno, W. (2016). Library life style: Trend dan ide kepustakawanan. Yogyakarta: Ladang Kata.

Trilling, B., and Hood, P. (1999). Learning, technology, and education reform in the knowledge age. Retrieved, August 2, 2019 from https://www.wested.org/online_pub/ learning technology.pdf).

Uswah, L.K. (2016). Konformitas: Adaptasi pustakawan di era masyarakat ekonomi ASEAN. Jurnal Info Persada, 14(1), 1-13.

Wahyuni, M. (2015). Peran pustakawan sebagai penyedia informasi. Jurnal Iqra', 9(2), 3953.

Zed, M. (2014). Metode penelitian pustaka. Jakarta: Yayasan Pustaka Obor Indonesia. 